日本地下水学会会誌 第14巻 第 1 号 1972

電気アナグロモデルによる地下水解析の技術的諸問題 I

一一主として連続アナログモデルについて——

庄田正宏*

\title{
Technical Problems of Electric Analog Model for Ground Water Analysis Part I A continous analog model
}

\author{
Masahiro SHODA
}

\begin{abstract}
The author made experiments on ground water flow with two type electric analog models: One is a continuous model and another is adiscrete model.

It is the purpose of this paper to point out several technical problems of these analog models. Two dimensional horizontal flow is dealt with in continuous analog model. In this model, the analogy between fluid flow through porous media and flow of electricity through conductive materials is considered taking two factors into account. They are the form of boundary and the distribution of potentials.

An analog apparatus is comprised of a power supply, an analog analyser, a probe and a pantograph. Potential distribution is measured on analog model. An analogyanalyser which uses the principle of wheatstone's bridge, and a potential dividers which give several potentials separately to analog model were made dy the author Asheet of cardon paper is used as a conductive material. The electrode is made by bending wire plated by tin and is attached to model by conductive silver paint. Areal differences in permeability are expressed by carbon paint. The conductive paper having the same shape as the actual field with a scale of $1 / 50,000$ is constructed and silver paint or carbon paint are painted so as to represent field condition such as flood plain, old river channel, etc.

Lastly, error or reliability of the continuous analog model are examined. Following problems are listed up.

1) When a electrode is small, the contact resistance between electrode and conductive paper became important and measured values become unstable.

2) The model can not express areal differences in permeability quantitatitvely.

3) In high voltage area of an analog model, sensibility of galbanometer is too high to measure a potential distribution.

4) The continuous electric analog with conductive paper is suitable of simple systems, for example, a seepage flow an earth dam and a channel.
\end{abstract}




\section{1.はじめに}

システム的研究の一手法としてシミュレーションがある。この方法は, 現象をよりわかりやすい システムに置きかえて解析できる，実際の現象の時間を調節できる。また現象を記録できるものに 置きかえられるなどの数多くの特徵を持っている。電気アナログ解析はこのうちの一つであって, 水文学の分野にも応用され, 欧米では多くの事例研究が発表されている。しかし日本においては, いまだ数例しかない。その原因は，一般にアナログ解析はハード部門とソフト部門の区別がはっき りせず，かつ実際の運用にあたっては，多くの電気技術的な問題を含んでいるためであると考方ら れる。

そこでこの論文では, 電気アナログ解析の原理と, 筆者が行ったアナログモデルを使った地下水 解析についての基礎的な実験を通して把握した技術的な問題点について述べる。

\section{2. 従来までの研究}

Kirchhoff は, 1845年に電導性物質を使ったアナログモデルの方法を最初に提唱した。その後こ の方法は, フィールド問題を解く有効な手段として, 電子工学, 電磁波, 磁場, 弾性波, 熱伝導な どに関する分野で研究された。

流体力学へ応用されたのは1920年代になってからで, その最初の研究はPuppini (1921) の浸透 水の挙動に関する研究に電気アナログを使ったものである。

戦後は, コンピューターの発達とともに, シミュレーションの一つの手法として多くの研究がな されるようになった。しかし，これらの研究のほとんどは，土木工学や物理学の方面の研究者たち によって行なわれており，水文学に盛んに用いられるようになったのは最近のことである。

アナログモデルによる水文学に関する研究を方法とテーマによって分類すると次のようになる。 方法としては，連続モデルと不連続モデルに分けられる。両者は原理的には同じもので，对象とな るシステムのフィールドを, 連続的に表現するか, 不連続で表現するかの相違である。基礎方程式 の性質から，一般に不連続モデルのほうが複雑な問題を取扱うことができる。

モデルで扱う次元は, 二次元が圧倒的に多い。浸透流や土壤水分を扱った場合は，垂直断面の二 次元であり，流域を扱った場合は水平二次元である。三次元モデルはふつうの場合はほとんど使わ れず，不連続モデルでは揚水井のモデル化など特殊な例に限られている。

テーマで分けると, 単独の水理現象を解析したもの, 流域の水の流動を水収支の立場から明らか にしたもの，井戸のモデル化などの技術的なものの三つに分けられる。

\section{3. 電気アナログ解析の原理}

実際の現象やシステムを電気のシステムに置きかえるには, 自然界に内在するアナロジー（相似 性）を利用する。たとえば物体の運動系と電気の運動系とのアナロジーが考えられる。物体と電気 とでは，それぞれのファクターは異なるが，その運動を表わす方程式の形が同じであれば，アナ口 ジーは成立する。水文現象にもこれがあてはまる。

つまり図1において，多孔質媒体中を流れる流体に関するDarcyの法則と，電遒体を流れる電流 に関する $\mathrm{Ohm}$ の法則との対応である。Darcyの法則から

$$
Q=K \Delta y \Delta z \quad\left(\frac{\Delta h}{\Delta x}-\right)
$$



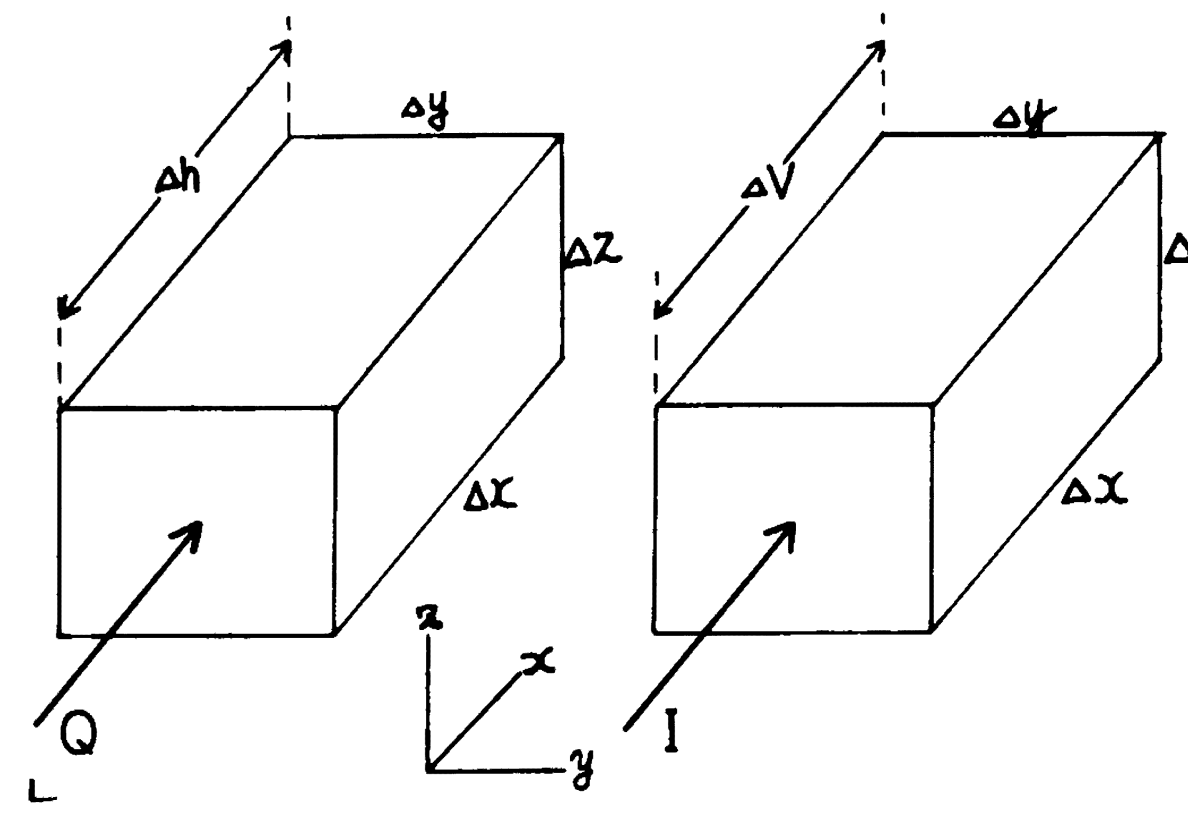

図 1 多孔質媒体を流れる流体と電導体 を流れる電流とのアナロジー

ただし， $Q$ : 流量, $k$ : 透水係数, $h:$ 水頭, 一方 $\mathrm{Ohm}$ の法則から

$$
I=\frac{V}{R}
$$

$\Delta Z$ 抵抗に関しては

$$
R=\frac{1}{\sigma} \frac{l}{A}=\frac{1}{\sigma} \frac{\Delta x}{\Delta y \cdot \Delta z}
$$

だから

$$
I=\sigma \Delta y \Delta z\left(\frac{\Delta V}{\Delta x}\right)
$$

ただし，I：電流の強さ， $\sigma$ : 比 電導度あるいは比抵抗の逆数, $V$ :電位, $R$ : 抵抗, $l$ : 抵抗体 の長さ， $A$ : 抵抗体の断面積。

(1)式と(2)式の対応は, 二つの現 象の間にアナロジーが成立し，流 体の流れが電気の流れによって模擬されることを示している。そして次のように同じオーダーにあ るファクターどうしがそれぞれ対応関係にある。

\begin{tabular}{l|l} 
地 下 水 系 & 電 気 系 \\
流量 $: Q$ & 電流の強さ $: I$ \\
透水係数: $k$ & 比電導度 $: \sigma$ \\
水頭 $: h$ & 電位 $: V$
\end{tabular}

程式で表わされ

$$
\frac{Q^{2} h}{Q x^{2}}+\frac{Q^{2} h}{Q y^{2}}=0
$$

ここで図 2 のような帯水層を考之，その繸横の 長さを $\Delta y, \Delta x$ に細分すると，差分近似によっ て点 0 について(3)式の左辺はそれぞれ

$$
\begin{aligned}
& \frac{Q^{2} h}{Q x^{2}}=\frac{h_{1}+h_{2}-2 h_{0}}{\Delta x^{2}} \\
& \frac{Q^{2} h}{Q y^{2}}=\frac{h_{3}+h_{4}-2 h_{0}}{\Delta y^{2}}
\end{aligned}
$$

さらに，带水層が均質等方性であるとすると

$$
\Delta x=\Delta y=a
$$

だから(3)式は

$$
h_{1}+h_{2}+h_{3}+h_{4}-4 h_{0}=0
$$

さて, 本研究で問題とした地下水の流れは, ポテンシャル方程式で示される定常流と，拡散 方程式で表わされる非定常流で，いずれも二次 元で取扱った。これらの式と電流に関する式と のアナロジーを差分近似を使って証明する。

涌出しも吸込みもない定常流は Laplace 方

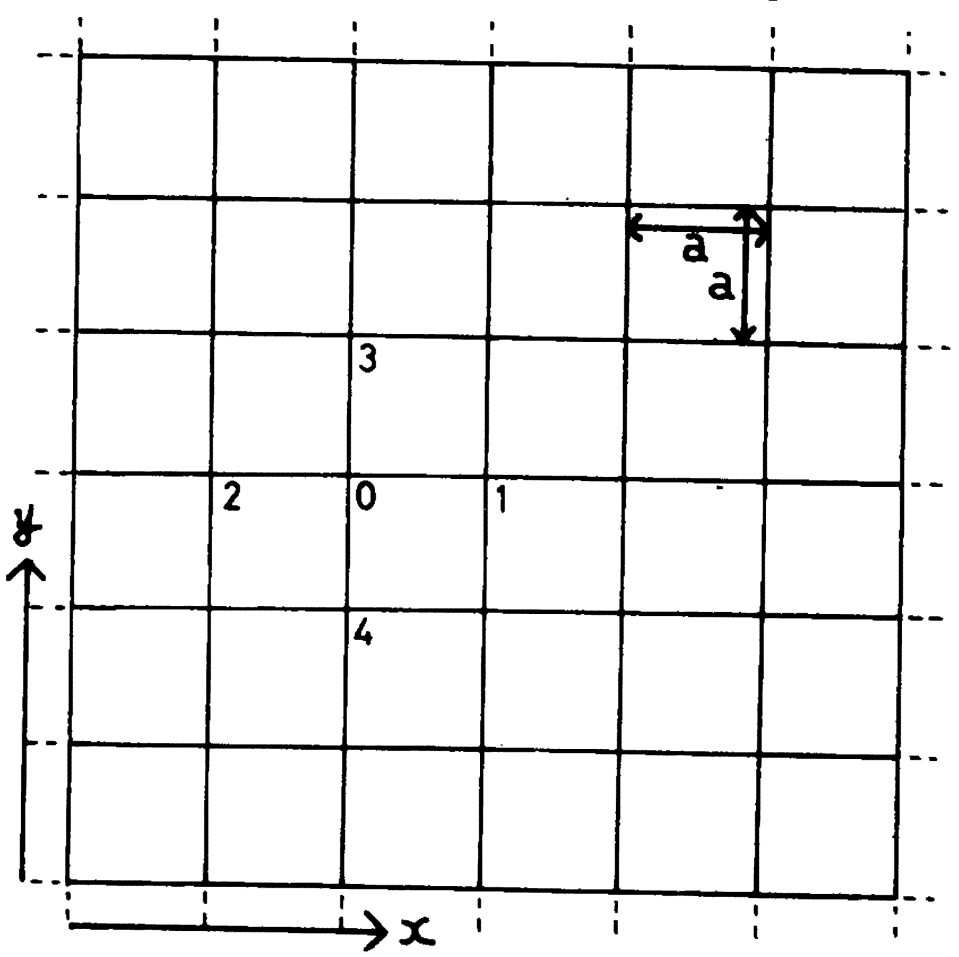

図 2 均質等方性二次元のフィールド 
一方，図3aのような抵抗の回路を考えると， Kirchhoff の法則によって点 0 に関して

全電流 $=0$

つまり

$\frac{V_{1}-V_{0}}{R_{1}}+\frac{V_{2}-V_{0}}{R_{2}}+\frac{V_{3}-V_{0}}{R_{3}}+\frac{V_{4}-V_{0}}{R_{4}}=0$

$R_{1}=R_{2}=R_{3}=R_{4}$ とすると

$$
V_{1}+V_{2}+V_{3}+V_{4}+4 V_{0}=0
$$

これで(4)式と(5)式が対応し，アナロジーが成立 する。

同じ定常流でも，涌出しや吸込みがある場合 はPoisson 方程式で表わされる。

$$
\frac{Q^{2} h}{Q x^{2}}+\frac{Q^{2} h}{Q y^{2}}=E
$$

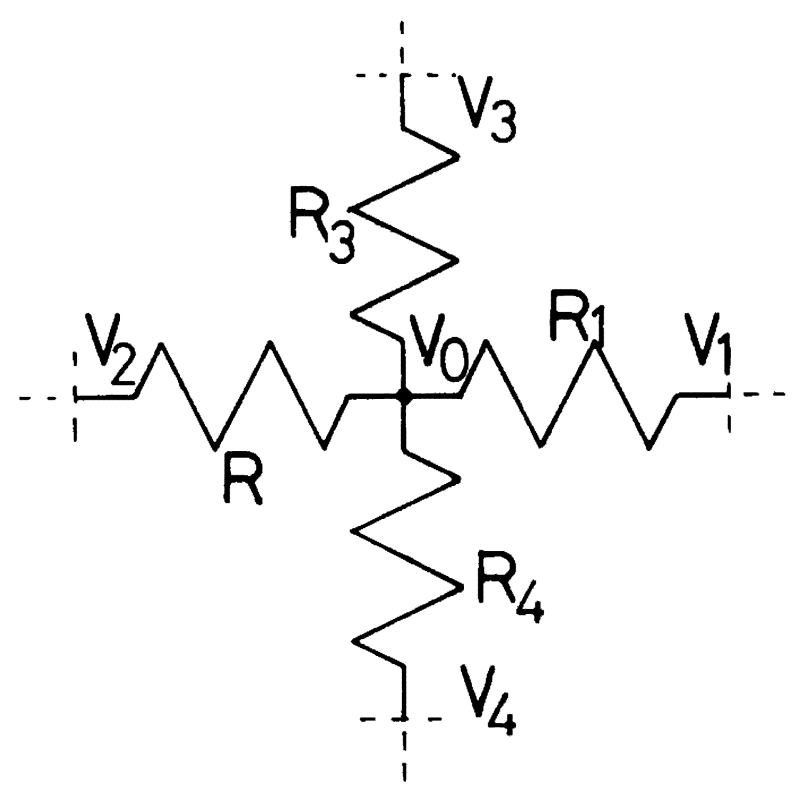

(a)

図 $3 \mathrm{a}$ 不連続アナログモデルの基本回路

ただし， $E$ : 湧出しあるいは吸込みの量差分近似と均質等方性によって(6)式は,

$h_{1}+h_{2}+h_{3}+h_{4}-4 h_{0}=E$

この場合は図3bのような回路を考え，点 0 にIampereに相当する電流を流せば,

$$
V_{1}+V_{2}+V_{3}+V_{4}-4 V_{0}=I
$$

(7)式と(8)式の間にアナロジーが成立する。

非定常流については，Jacob(1950)に定義した方程式で次の形をとる。

$$
\frac{Q^{2} h}{Q x^{2}}+\frac{Q^{2} h}{Q y^{2}}=\frac{\mathrm{S}}{\mathrm{T}} \frac{Q h}{Q t}
$$

ただし， $S$ : 貯留係数, $T$ : 透水量係数, $t$ : 時間 差分近似によって(9)式は,

$$
\frac{h_{1}+h_{2}-2 h_{0}}{\Delta x^{2}}+\frac{h_{3}+h_{4}-2}{\Delta y^{2}} \frac{h_{0}}{-}=\frac{S}{T} \frac{Q h}{Q t} \cdots(10)
$$

帯水層が均質等方性で，細分した格子の間隔を $a$ とすると,

$$
T\left(h_{1}+h_{2}+h_{3}+h_{4}-4 h_{0}\right)=a^{2} S \frac{Q h}{Q t}
$$

ここで, 図3cのような抵抗とコンデンサーの 回路を考えると, 点 0 についてKirchhoff の法 則から

$$
\frac{V_{1}-V_{0}}{R_{1}}+\frac{V_{2}-V_{0}}{R_{2}}+\frac{V_{3}-V_{0}}{R_{3}}+\frac{V_{4}-V_{0}}{R_{4}}=
$$

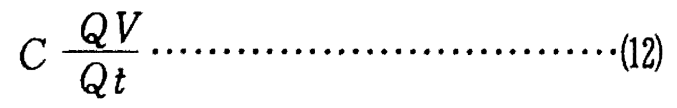

ただし，C：電気容量

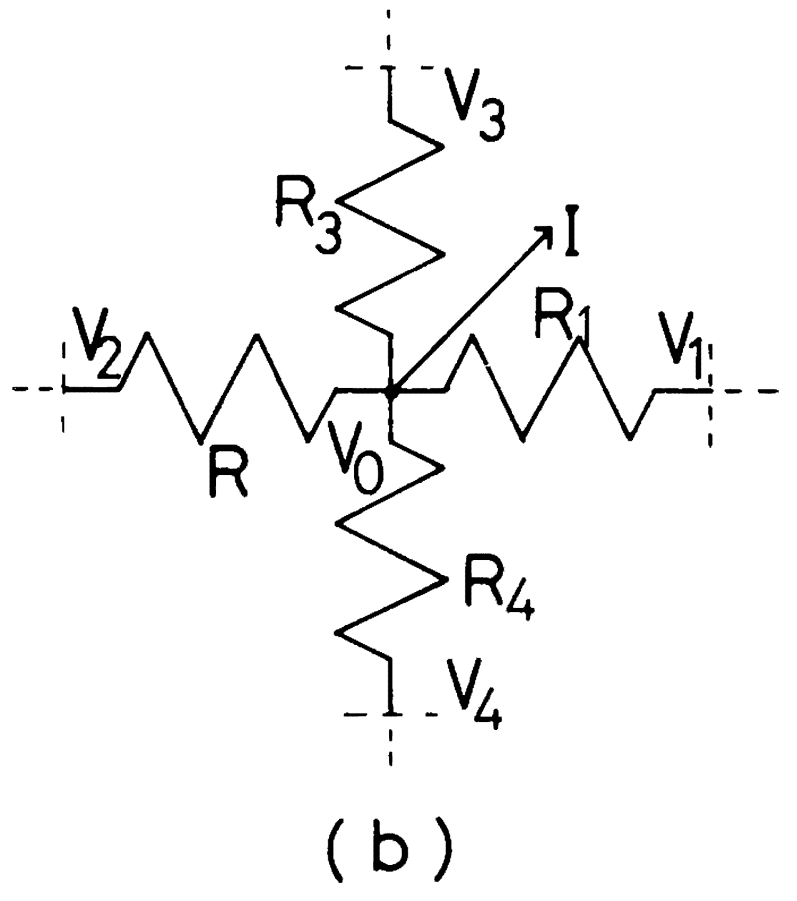

図 $3 \mathrm{~b}$ 不連続アナログモデルの基本回路 


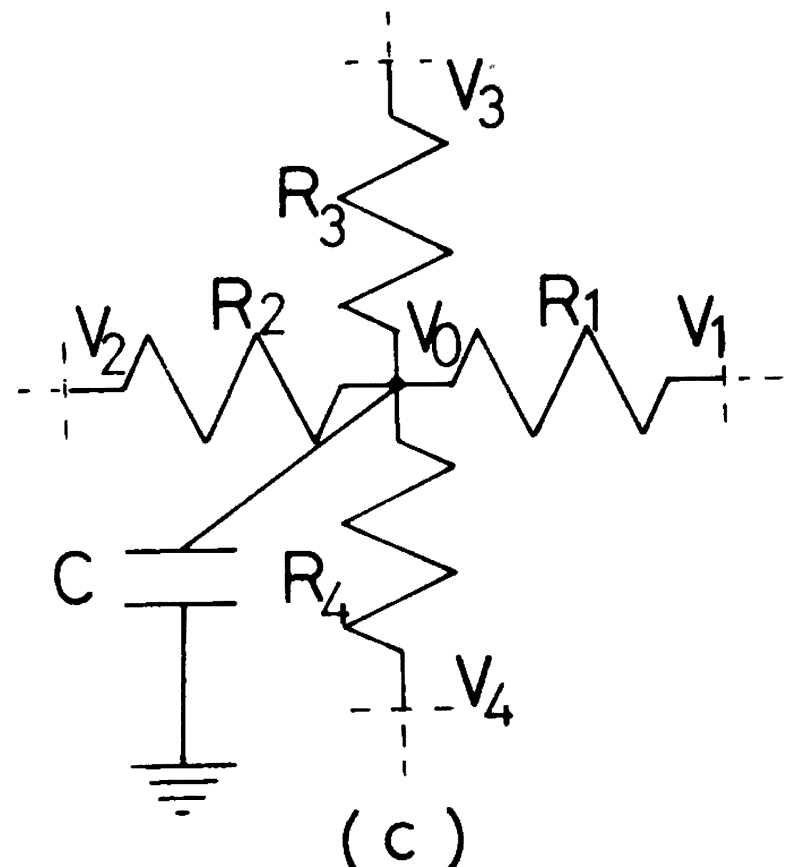

(c)

図 3c 不連続アナログモデルの基本回路

$R_{1}=R_{2}=R_{3}=R_{4}$ とすると

$$
\frac{1}{R}\left(V_{1}+V_{2}+V_{3}+V_{4}-4 V_{0}\right)=C \frac{Q V}{Q t} \cdots \cdots(12)
$$

これで(11)式と(12)式が対応し，非定常な二次元の 地下水流と, 抵抗コンデンサー回路を流れる電 流との間にもアナロジーが成立する。

本研究では，アナグロモデルの材料の特性か ら，定常流については電導紙を使った連続モデ ル，非定常流については抵抗とコンデンサーを 使ったいわゆるRC回路を用いて解析を行った。

\section{4. 連続アナグロモデルによる解析}

この場合は，(4)式と(5)式とが対応することか ら，ポテンシャルに関するファクターだけでア ナロジーは成立することになる。つまり, Laplaceの式で表わされた定常流を模擬するアナログモ デルでは, ポテンシャルの相似性と境界条件の配置が同じであればよいのであって，モデルの電導 性, 逆に言之ば固有抵抗值は関係ないことになる。したがって求めた解は, あくまでポテンシャル 分布のみであって，それから透水係数や流量の值を出して論じることはできない。これらを間題に するときは，透水係数に対応する抵抗をもった材料でスケールモデルを作り，電流值も合わせなけ ればならない。

1) 解析装置とモデルの材料

連続アナログモデルで問題とする流れは定常流なので，アナログモデルを通る電流は，ある電位 をもった直流になる。したがってモデルに与える電流は直流で，モデルは抵抗体だけの構成となる。

アナログモデル内のポテンシャルの分布を解析するには，ホイートストンブリッジの原理を応用 する。図4aのPとQがが同じ電位であると, $\mathrm{PQ}$ 間に電流は流れず、検流計 Gはゼロを示す。 このとき

$$
\begin{aligned}
R_{1} / R_{2} & =R_{3} / R_{4} \\
R_{1} R_{4} & =R_{2} R_{3} \\
\therefore R_{1} / R & =R_{2} / R_{4}
\end{aligned}
$$

図 $4 \mathrm{a}$ の抵抗 $R_{2}, R_{4}$ にあたる 部分を一つの 可変抵抗器にして, 抵抗 $R_{1}$ と $R_{3}$ をアナログモ ルの一つの抵抗に置きかえる。（図 $4 \mathrm{~b}$ )

こうして, 可変抵抗器のある值に对して,つ ねに検流計の指針がゼロを指すように，プロー ブでアナログモデル上を追っていけば，それに よって等電位線，あるいはそれと直交する流線 が描ける。それはつまり, 可変抵抗器の $R_{1}$ と $R_{2}$ の比に，アナログモデルの抵抗を配分している

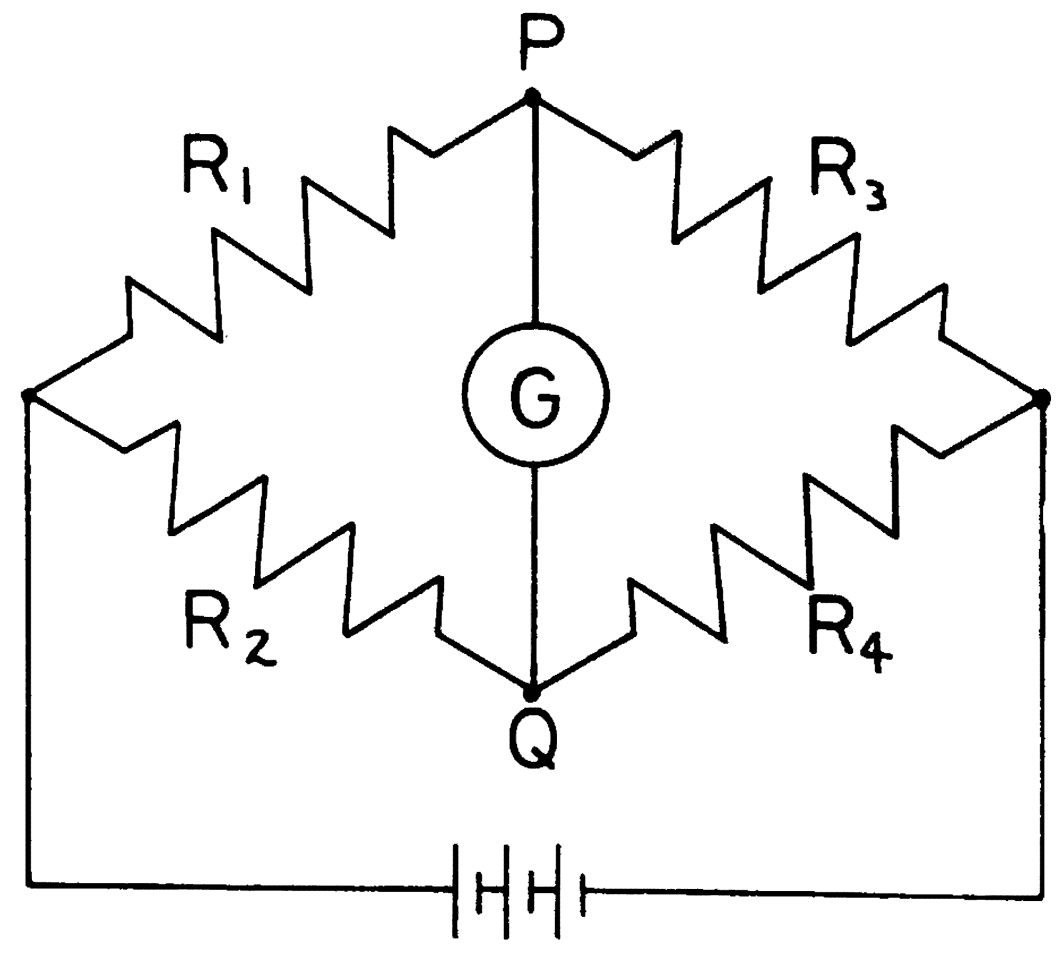

図 4a 連続アナログ解析の原理 
ことになる。

またより多くの条件を入れてフィールドを 再現するためには，解析本来の電位とは別に電 位が認定できるポテンシャルデバイダーが必要 である。これは抵抗によって電源から直接取る ことができる。

以上の原理にしたがって製作した解析装置の 構成は, 図 5 のようになっていて, 電源, 解析 器, プローブ, パンタグラフ, アナログモデル などからできている。

\section{(a) 電源と解析器}

電源は直流安定化電源で, 家庭用の交流100ボ ルトを直流にする整流部と, 入力電圧の変化に かかわらず電圧を一定に保つ電压安定化部から できている。使用電流はわずかであるが, 出力

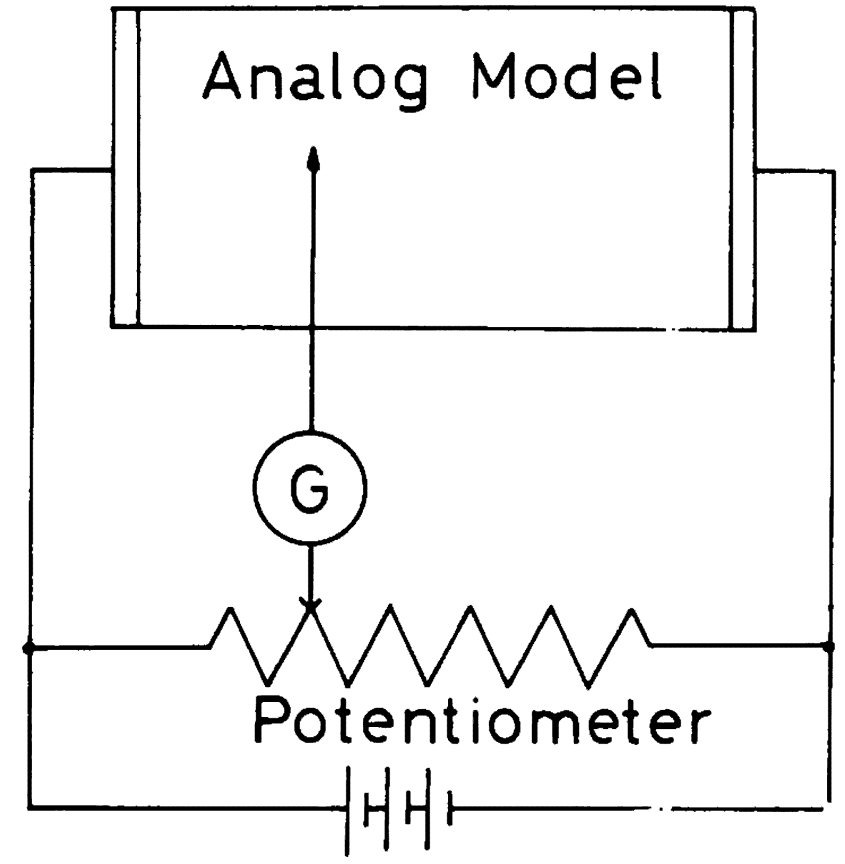

図 $4 \mathrm{~b}$ 連続アナログ解析の原理

電圧はなるべく広範囲に，しかも連続的に変えられるものが便利である。安定した解析を行うため にはこのような定電圧電源を使うことが望ましい。

解析器には, 検流部にあたるポテンシオメーターと, 別に境界条件を与えるポテンシャルデバイ ダーが一緒に納められていて，その回路は困6のようになっている。

ポテンシャルを選択するためのポテンシオメーターには, 精密な可変抵抗器を使っている。これ は軸が10回転するので、1/1000まで読み取ることができる。さらにパネルには，この抵抗器にバー ニアダイアルを取りつけて使いやすくしてある。等ポテンシャル線を描くときに，ポテンシオメー ターとアナログモデル上の点とが同じ電位にあることを確認するのが検流計である。アナログモデ ルに与える電圧は，抵抗体の変化を避けるために，なるべく低いほうがよいが，検出をするのに十 分な高さでなければならない。

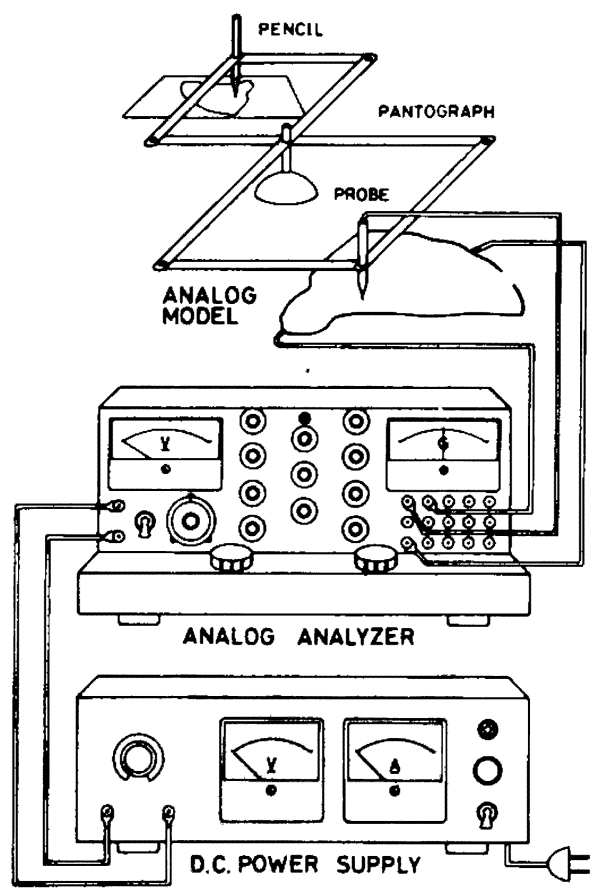

図 5 連続アナログ解析装置の構成

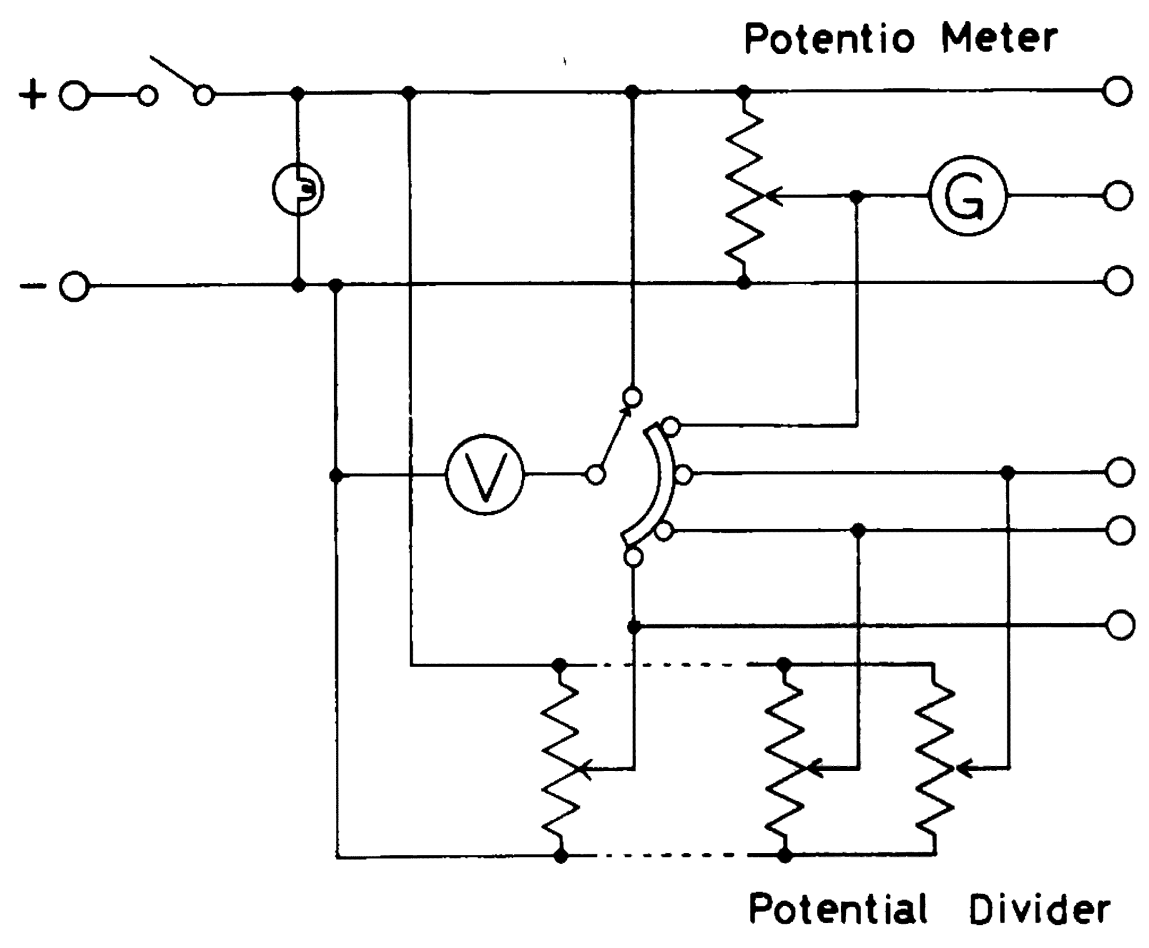

図 6 解析器の回路 
ポンシャルデバイダーでは，自由にポテンシャルをを設定できるように，やはり可変抵抗器を使 用したが, コストの関係から普通の通信器型にした。これも前記の精密なものにすれば, もっと細 かく設定できる。解析器には, 入力電圧の確認, ポテンシャルの選択, 設定などのときに電圧を読 み取るために，直流電圧計も取りつけてある。

(b) プローブとパンタグラフ

プローブは，アナログモデルに直接触れて電位を探るので，測定精密の点から言えば，先端は細 いほうが優れている。しかしあまり細いと，アナログモデルの抵抗体を破壊してしまう危険性があ る。このため筆者は, 市販のボールペンの先に、コードを取りつけて使用したが, なかなか具合が 良かった。

得られた等ポテンシャル線を，アナログモデル上にプローブで押しつけて書いてしまうと抵抗が 変化すると同時に, 後の実験に使えなくなってしまう。そこで, パンタグラフを使って他の紙にト レースするようにした。ところが, パンタグラフの作り方が悪く少しがタがあったので, 測定精度 を欠く結果になってしまった。やむを得ず今回の実験では，なるべく軽く押すようにして，モデル 上に等ポテンシャル線を描いた。

(c) アナログモデル

連続電気アナログで，問題の対象となるフィールドを形成しているのは，ある一定の抵抗を持っ た電導性の物質で, 固体では電導紙, 電導㵶維, 電導ゴム, 電導プラスチックなどがあるが, 最も 使われているのは電導紙である。筆者が手に入れた電導紙は，次の二種類である。

一つは,「Teledeltos」という商品名で，1948年に米国Western Telegraph Campanyによって開 発されたもので，電信の記録紙として使われているようである。この紙の電導紙の本体はカーボン ブラックで，製造過程で紙パルプにまぜて作られる。紙の一方の面はラッカーがコーティングされ ていて絶縁されており，他方の面は，アルミこウムが塗布されている。紙の両側は電導性はよくな いが, アルミニウム層は 1 ミクロンの厚さなので, プローブや電極が簡単に貫くことができる。

Teledeltos Paperには大きく分けてLowとHighがあって，筆者が入手したのは，Lー39という 単位面積当りの抵抗が約 $2.2 \mathrm{~K} \Omega$ のものと, $\mathrm{H}-62 \mathrm{~s}$ という約 $11.5 \mathrm{~K} \Omega$ のも，それから製品番号は不 明だがHighで約15K $\Omega$ ののである。

製造過程において抵抗值の細かいコントロールができないので製品のバラツキは約 $\pm 10 \%$ また異方性がある，紙の縦方向（ロー元方向）は，横方向に比べて約10\%低い抵抗値である。また 一般に抵抗体は温度によって抵抗值が変化し，Carbon の場合温度が上がれば抵抗値は下る。その

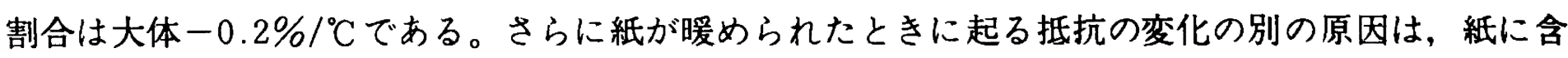
まれる水分による湿度の変化である。したがって, Teledeltos Paper を使って正確な解析を行う には，温度や湿度をコントロールした状態で行わなければならない。

もう一種類の電導紙は，米国で教材用に造られているInterpretation Systems Incorporated社の アナログ解析器「Field Plotter」に付属しているもので, 紙の一方の側にカーボンブラックが塗布

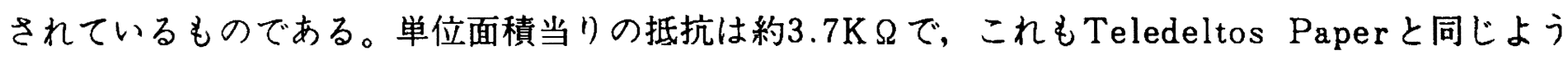
な傾向をもっている。しかしTeledeltos Paperよりも異方性は小さいし，温度や湿度の変化に対 しても比較的安定しているもので，常温で使うかぎりは問題はないと思われる。

以上のようないくつかの欠点にもかかわらず電導紙がよく使われるのは, 安価なことと, 簡単に 裁断できるので，自由にフィールドを再現できるという簡単性による。 
筆者は性能のすぐれている後者の電導紙を使用した。

(d) 電極と Silver Paint, Carbon Paint

アナログモデルに一定のポテンシャルつまり電位を与えるには，モデルが紙なので，入力あるい は出力となる場所に電極を設ける。電極は電導紙に比べて抵抗が無視できるものでなければならな いが，実験ではスズメッキ線を境界の形に折り曲げて作り，電導紙の上に電導性の塗料兼接着剂で 取りつけた。この薬品は，米国Dupont社のSilver Paint №.4817 と No.4922 というもので，その名 のごとく銀粉が主成分であるらしく，これが電気を通す役目をしている。溶剂としては,アセトン， 酢酸ブチルなどが使える。このSilver Paintを使ったのは,電極を電導紙に圧着したのでは接触抵 抗が大きくなってしまうし，また紙の電導体を破壊してしまって，その部分の抵抗值が変化してし まうからである。

基本的なモデルでは電導紙をそのまま使い，透水性はどこも等しいと仮定したが，後の実験では 部分的に透水性を変えた。それに使われたのはカーボンブラックの粉末を溶したもので, 米国Dynaloy社のConductve Carbon である。これは溶きかたによって濃くも薄くもなるので，自由に電導 性を変えることができる。しかし，各々の濃度でどの程度抵抗が変わるかは実験していないのでわ からない。また筆で慗るので塗りむらができたりして均等にはいかない。

2) フィールドの境界条件とそのモデル化

フィールドの境界条件としては，次のものが考えられる。

(a) フィールドの形

フィールドの形は，電導紙を鋭いナイフで切断することによって，自由に作り出すことができる。 縮尺は, 紙の大きさと測定精度から適当に決める。タンクモデルでは, 電解液を入れる器をその境 界に合わせてつくらなければならないのでかなり面倒である。

(b) 等ポテンシャル境界

等ポテンシャル境界は，その部分にSilver Paintを塗ったり，金属䇴を貼ったりすればよく， 電極もこのなかに含まれる。

（c）流れを促進する条件，防げる条件

流れを促進させるものとしては, 高い透水係数や水路などがある。この問題は, Carbon Paint で電導性を高めることによって解決される。その程度に応じて塗る回数を多くすればよい。逆に防 げるものがあるときは，その部分に穴をあけたり，切断したりして電導性を下げる。

(d) 特別なポテンシャル

フィールド内に 特別なポテンシャルを作り出すには, 直流電源とポテンシャルデバイダーを使っ て, いくつかの不連続な点電極で電位を与えればよい。しかし，もとのポテンシャル（電位）勾配 と別に与えた電位とに大きな差があると，測定が不安:定になりやすい。

(e) 特別な流れ

フィールド内に吸い込みや涌き出しがあるときは, 前述のPoissonの方程式を考之た場合である。 これを可能にする定電流電源は, 高い電圧の定電圧雪源と, アナログモデルに比べてはるかに大き な抵抗によって近似的につくり出されるが，簡単なことではない。スケールモデルをつくる場合に もこれが言える。

以上の方法によって，実際のフィールドの境界条件により忠実な連続アナログモデルを作成する ことができる。 
3) 解析例

連続アナログモデルの解析例を第 7 困に示す。

これは富山県黒部川扇状地で，現沖積扇状地 面について，地下水は扇頂から扇端へ一方的に 流れ，他の地域からの出入りはないものとして, 水頭 $10 \mathrm{~cm}$ につ $1 \mathrm{~V}$ の割合で電位を与之た場合 の等水頭線をメートルで表わしてある。なお透 水性は河川や水路の部分で変えてある。

これは途中の段階の解析例なので, 実測値と は違っている。

4 ) 連続アナログ解析の誤差

電導紙を使ったアナログモデルについて，得 られた解析值が実測值と合うかどうかというこ とではなく, 解析值そのものの信頼性に関して, その問題点を述べる。

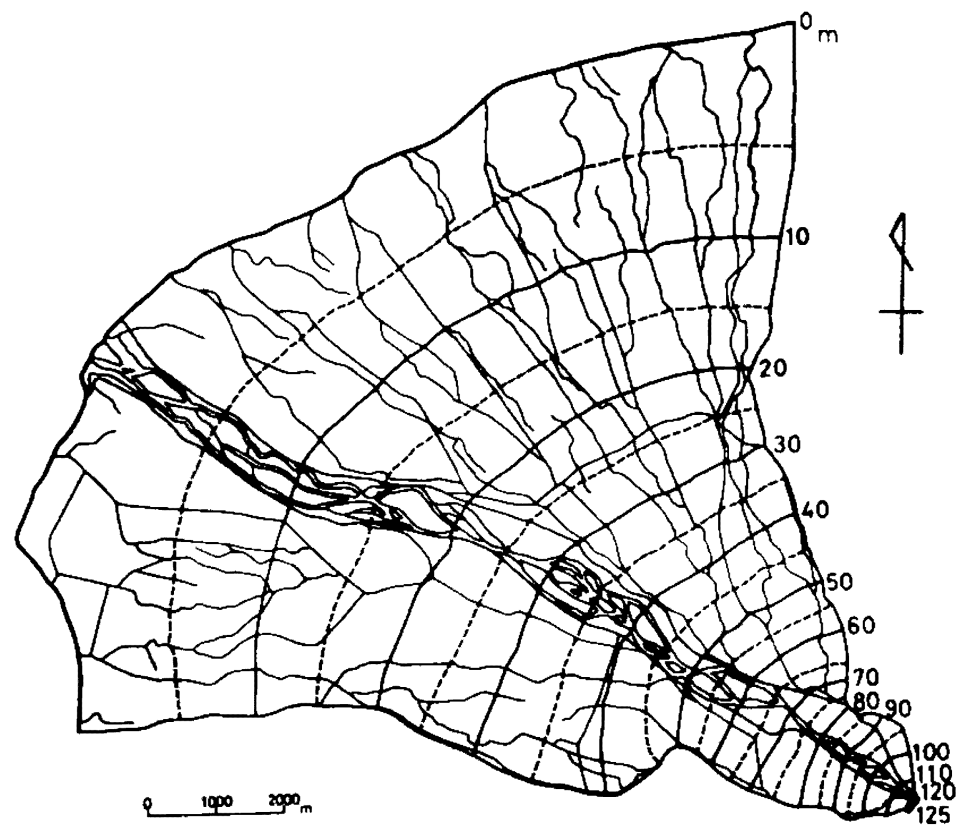

図 7 連続アナログモデルによる解析例

信頼性を危くするもととして，次の三つの問 題点があげられる。

(a) 電極を取りつけたり等ポテンシャル地域をつくり出すために, Silver Paintを使うことにつ いて前に述べたがこれは接触抵抗を小さくするためであった。

しかし小さな点電極の場合に，接触抵抗が表われて不安定な值を示すのもあった。これについて は，緒形（1960）が指摘しているが，電導紙と電極の間に接着剂の薄い膜ができるためであるらし い。緒形はこの点に関して二三の解決法を行ったが, 筆者の研究では電導紙が違うので, まだ完全 に解決する方法が見つからず，今後に残された課題の一つである。

（b）電導性（透水性）を部分的に変えるためにCarbon Paintを使用したが，この溶きかたによ って Carbonの濃度が変わって，塗るごとに電導性が違う。

また筆で塗るため塗りむらができてしまう。

これらの久点は，モデルの条件が均一に与えられていないことになる。

(c) 電位の低いところでは，検流計の感度はちょうどよくて，測定しやすい振れを示すが，電位 の高いところではそれだけ流れる電流の強さも大きいので，振れすぎてしまい测定しにくく不安定 な原因を起している。 